\title{
Santa Rita Experimental Range Long Term Transect Database
}

\author{
Mitchel McClaran
}

\begin{abstract}
Measures of plant cover and density are available from 130 permanent transect locations on the 21,000 ha Santa Rita Experimental Range. This long-term research area stretches across the western alluvial skirt of the Santa Rita Mountains, about $50 \mathrm{~km}$ south of Tucson, Arizona ( $\left.31^{\circ} 50^{\prime} \mathrm{N}, 110^{\circ} 53^{\prime} \mathrm{W}\right)$. Elevation increases from about 900 to $1,450 \mathrm{~m}$, with a corresponding increase in annual precipitation from 275 to $450 \mathrm{~mm}$ (fig. 1). Transects were established between 1956 and 1972 and were re-measured every year from 1956-1966, and every three years from 1972-2009 (except 1987). Transects are $30.4 \mathrm{~m}$ long and $0.31 \mathrm{~m}$ wide, and line intercept measured on the long axis provides an estimate of grass basal cover and shrub canopy cover, and counts of plants rooted in the 9.28 $\mathrm{m} 2$ area provide estimates of plant density. All previous measurements and UTM coordinates are available on the Santa Rita web site (http://ag.arizona.edu/srer). This report describes the available content in the vegetation-plot database "Santa Rita Experimental Range Long Term Transect Database" (GIVD ID NA-US-005).
\end{abstract}

Keywords: cover; density; long term data; transect.

\section{Santa Rita Experimental Range Long Term Transect Database}

Scope: Measures of plant cover and density are available from 130 permanent transect locations, that were established between 1956 and 1972 and were re-measured every year from 1956-1966, and every three years from 1972-2009 (except 1987). Transects are $30.4 \mathrm{~m}$ long and 0.31 m wide. All previous measurements and UTM coordinates are available on the Santa Rita web site (http://ag.arizona.edu/srer).

Status: completed and continuing

Period: 1954-2009

Database manager(s): Mitchel McClaran (mcclaran@u.arizona.edu)

Owner: Mitchel McClaran

Web address: http://ag.arizona.edu/SRER/data.html

Availability: free online

Online upload: yes

Online search: no

Database format(s): Excel

Export format(s): [NA]

Publication: Santa Rita Experimental Range Digital Database: User's Guide

Mitchel P. McClaran, Deborah L. Angell, and Craig Wissler

September 2002

USFS Forest Service General Technical Report RMRS-GTR-100

Rocky Mountain Research Station, Ogden, Utah

Plot type(s): time series

Non-overlapping plots: 132

Total plot observations: 2,084

Plot-size range: $9-9 \mathrm{~m}^{2}$

Countries: US: $100.0 \%$

Estimate of existing plots: 132

Completeness: $100 \%$

Forest: $0 \%$ - Non-forest: aquatic: 0\%; semi-aquatic: 0\%; arctic-alpine: 0\%; natural: 100\%; semi-natural: 0\%; anthropogenic: 0\%

Guilds: all vascular plants: $100 \%$

Environmental data: altitude: $100 \%$; surface cover other than plants (open soil, litter, bare rock etc.): $100 \%$; other soil attributes: $100 \%$

Performance measure(s): cover: $100 \%$; other: $100 \%$

Geographic localisation: GPS coordinates (precision $25 \mathrm{~m}$ or less): $100 \%$

Sampling periods: 1950-1959: 10.0\%; 1960-1969: 18.0\%; 1970-1979: 18.0\%; 1980-1989: 12.0\%; 1990-1999: 18.0\%; 2000-2009: 24.0\%

Information as of 2012-07-12; further details and future updates available from http://www.givd.info/ID/NA-US-005

Mitchel McClaran (mcclaran@u.arizona.edu)

Natural Resources and the Environment, University of Arizona, 325 Bio Sci East, 85721 Tucson Arizona, UNITED STATES 